\title{
Caloramator proteoclasticus sp. nov., a New Moderately Thermophilic Anaerobic Proteolytic Bacterium
}

\author{
SILVANA TARLERA, ${ }^{1 *}$ LUCÍA MUXÍ, ${ }^{1}$ MATILDE SOUBES, ${ }^{1}$ AND ALFONS J. M. STAMS ${ }^{2}$ \\ Departamento de Microbiologí, Facultad de Química y Facultad de Ciencias, Universidad de \\ la República, Montevideo, Uruguay, ${ }^{1}$ and Department of Microbiology, Wageningen \\ Agricultural University, 6703 CT Wageningen, The Netherlands ${ }^{2}$
}

\begin{abstract}
A new moderately thermophilic proteolytic anaerobe, strain $U^{T}$, was isolated from mesophilic granular methanogenic sludge. The cells were spore-forming, motile rods that were $0.4 \mu \mathrm{m}$ wide and 2.4 to $4 \mu \mathrm{m}$ long and stained gram negative. Electron micrographs of thin sections revealed the presence of an atypical gram-positive cell wall. Optimum growth occurred at $55^{\circ} \mathrm{C}$ and at $\mathrm{pH}$ values between 7.0 and 7.5 , with a doubling time of $30 \mathrm{~min}$. The DNA base ratio of guanine plus cytosine was $31 \mathrm{~mol} \%$. The bacterium fermented proteins mainly to acetate, hydrogen, formate, and branched-chain fatty acids. Several amino acids, including glutamate, aspartate, arginine, histidine, threonine, methionine, and branched-chain amino acids, were also utilized. Glutamate was degraded to acetate, formate, hydrogen, and alanine. In addition, the strain degraded carbohydrates, including glucose, fructose, mannose, cellobiose, and starch, to acetate, ethanol, formate, lactate, and hydrogen. The results of a 16S rRNA sequence analysis phylogenetically placed strain $U^{T}$ in the low-guanine-plus-cytosine-content subgroup of the gram-positive phylum. We propose to classify the described strain in the genus Caloramator as a new species, Caloramator proteoclasticus. The type strain of $C$. proteoclasticus, strain U, has been deposited in the Deutsche Sammlung von Mikroorganismen as strain DSM 10124.
\end{abstract}

Many types of industrial wastewaters are treated successfully in methanogenic bioreactors $(17,30,32)$. Anaerobic treatment occurs in different stages. In a hydrolytic phase, biopolymers (polysaccharides, proteins, fats, and nucleic acids) are hydrolyzed and the easily degradable compounds are fermented mainly to fatty acids. These processes often occur in acidification tanks. In a methanogenic reactor, fatty acids are metabolized by acetogenic and methanogenic bacteria to methane and carbon dioxide.

The presence of large amounts of proteins is often disadvantageous for the efficient anaerobic treatment of waste. Proteins are poorly degraded in wastewaters from landfills, slaughterhouses, and tanneries and other wastewaters regularly regarded as easily degradable, e.g., those originating from fish industries, beer breweries, and baker's yeast factories, as well as whey $(15,20)$. Many industrial wastewaters are discharged at high temperatures. For such wastewaters, a thermophilic anaerobic degradative process is attractive (37).

In the past 2 decades many moderately thermophilic saccharolytic anaerobic bacteria have been isolated from different environments, but only a few moderately thermophilic proteolytic bacteria have been described (38). Coprothermobacter proteolyticus (13), Thermobacteroides leptospartum (35), and Clostridium strain P2 (24) are proteolytic bacteria isolated from fermentation sludge of cattle manure, cattle manure compost, and slaughterhouse waste, respectively. Recently, Anaerobranca horikoshii was isolated from a natural thermobiotic environment (5). In this paper we describe a novel proteolytic thermophilic anaerobe, Caloramator proteoclasticus, isolated from mesophilic granular sludge.

\section{MATERIALS AND METHODS}

Media and culture conditions. The peptone yeast medium of Holdeman et al. (10) supplemented with $0.4 \mathrm{~g}$ of glucose per liter was used for enrichment and isolation. The medium was prepared as described by Muxí et al. (23). Granular

* Corresponding author. Mailing address: Cátedra de Microbiología, Facultad de Química, Casilla de Correo 1157, Montevideo, Uruguay. Phone: 59829442 09. Fax: 59829419 06. E-mail: starlera@bilbo .edu.uy. sludge from a lab-scale upflow anaerobic sludge bed (UASB) reactor that was treating whey was used for isolation. Granules were crushed with a potter tube in an anaerobic glove box, and $2.5 \mathrm{ml}$ was transferred to a $120-\mathrm{ml}$ serum bottle containing $50 \mathrm{ml}$ of medium. The bottle was incubated for $24 \mathrm{~h}$ at $55^{\circ} \mathrm{C}$. Thereafter, the roll tube technique, as described by Hungate (12), was used to isolate bacteria. For this purpose $1.5 \%$ agar was used. Strain $\mathrm{U}^{\mathrm{T}}$ was obtained and studied further. The purity of the strain was confirmed by light microscopy, morphology of colonies streaked on agar plates, 16S ribosomal DNA sequence analysis, and pasteurization tests at $90^{\circ} \mathrm{C}$.

A defined bicarbonate-buffered mineral medium, prepared and dispensed as described by Houwen et al. (11) but supplemented with $0.2 \mathrm{~g}$ of yeast extract per liter, was used for the rest of the studies unless stated otherwise. Substrates were added from heat- or filter-sterilized anaerobic stock solutions. When amino acids were tested as substrates, $\mathrm{NH}_{4}{ }^{+}$was omitted from the medium. Gelatin agar plates were streaked and incubated in an anaerobic chamber. Growth rates were determined by measuring product formation in triplicate bottles over time. Product formation was analyzed after 2 or 3 weeks of incubation at $55^{\circ} \mathrm{C}$ by subtracting the amounts of end products obtained in control bottles containing yeast extract without added substrate.

The requirement of anaerobic conditions for growth was tested by inoculating stoppered shake tubes containing prereduced medium with a headspace of air. where an oxygen gradient developed (1)

Electron microscopy. Cells from an exponentially growing culture were fixed for $1 \mathrm{~h}$ at room temperature in $3 \%$ glutaraldehyde and $1 \% \mathrm{OsO}_{4}$ in $0.1 \mathrm{M}$ sodium cacodylate buffer, $\mathrm{pH}$ 7.2. Cells were dehydrated in graded ethanol and impregnated with epoxypropane. Subsequently, the samples were embedded in Epon 812. Ultrathin sections, 50 to $70 \mathrm{~nm}$ thick, were cut on an LKB ultramicrotome.

For negative staining, cells were fixed in $3 \%$ glutaraldehyde in $10 \mathrm{mM}$ sodium phosphate buffer, $\mathrm{pH}$ 7.0. A Formvar-coated copper grid (150 mesh) was placed on a drop of cell suspension for $15 \mathrm{~min}$. After the grid was washed with distilled water, cells were contrasted with uranyl acetate and the grid was air dried. Micrographs were taken with a JEOL transmission electron microscope.

Analytical methods. Most substrates and products were measured by highpressure liquid chromatography (HPLC) as previously described (34). Hydrogen and methane levels were determined quantitatively by gas chromatography (34). Amino acids were analyzed by HPLC, with dansyl chloride as a derivatization reagent, and were separated on an Inertsil 5 ODS- 2 column $(200 \mathrm{~cm}$ by $3 \mathrm{~mm})$.

$16 S$ rRNA sequence analysis. The $16 \mathrm{~S}$ rRNA gene was PCR amplified with the universal bacterial primers $7 \mathrm{f}$ and $1510 \mathrm{r}$ (16) under previously described conditions $(8,25)$. The resulting amplicons were purified and concentrated with the QIA Quick Kit (Qiagen GmbH, Hilden, Germany). Direct sequencing of both strands was performed by using an automatic sequencer, ABI 373A (Applied Biosystems, Foster City, Calif.), and the ABI PRISM DyeDeoxy terminator cycle sequencing kit (Applied Biosystems). All procedures were done according to the manufacturers' instructions. Gene database searching was performed in the EMBL database with the FASTA algorithm (27) via the CAOS/CAMM Center (Catholic University of Nijmegen, Nijmegen, The Netherlands). Multiple-sequence alignment was done with the Pileup program and manually adjusted to 

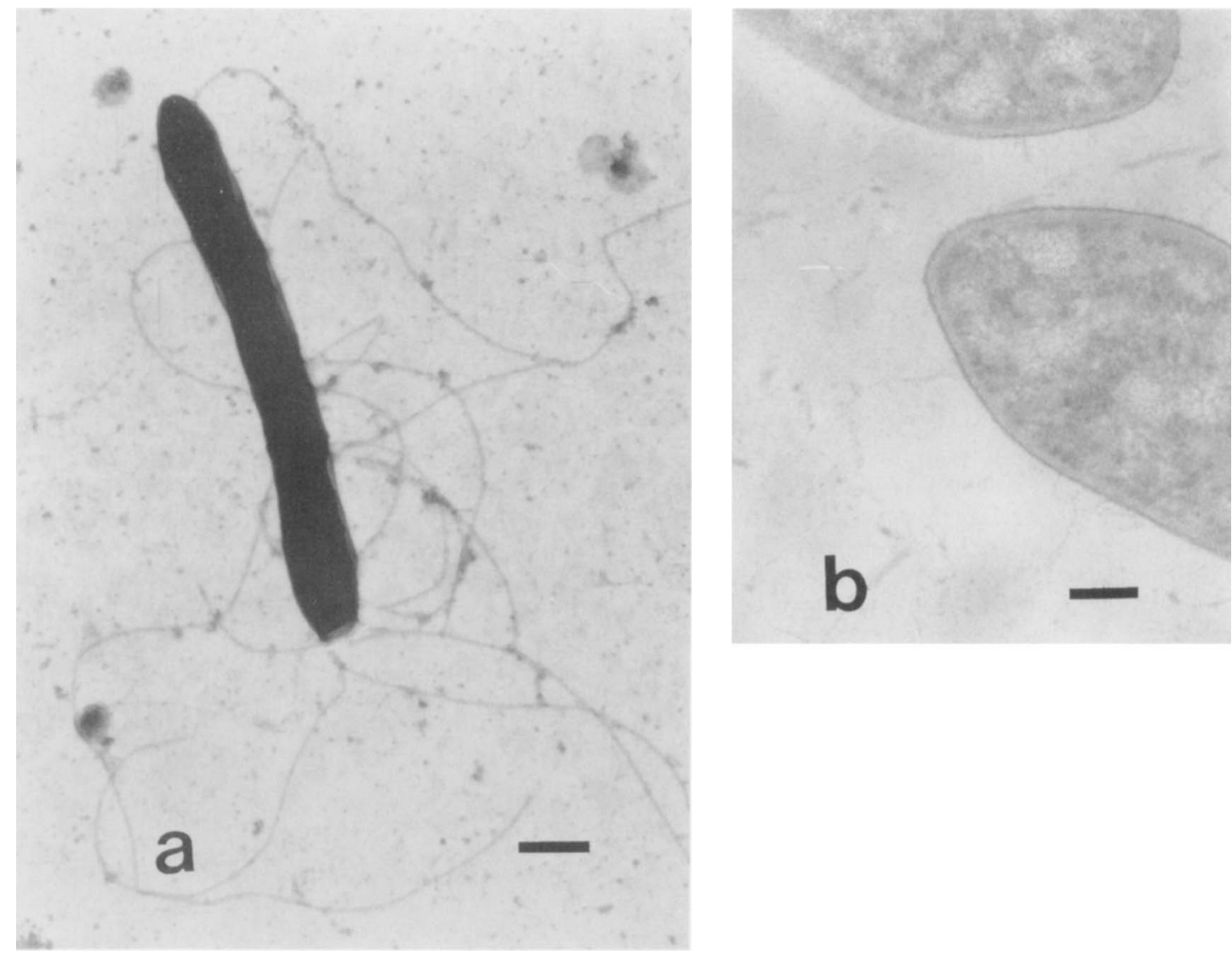

FIG. 1. (a) Electron micrograph of strain $\mathrm{U}^{\mathrm{T}}$, negatively stained, showing morphology and peritrichous flagellation. Bar $=0.5 \mu \mathrm{m}$. (b) Ultrathin section showing the atypical gram-positive cell wall structure of strain $\mathrm{U}^{\mathrm{T}}$. Bar $=0.1 \mu \mathrm{m}$.

remove regions of uncertain alignment. Phylogenetic analyses were performed with the TREECON version 2.2 software package (36). The method of Kimura (14) was used to calculate evolutionary distances, from which a phylogenetic dendrogram was constructed by using the neighbor-joining algorithm of Saitou and $\mathrm{Nei}(29)$. The reliability of the tree was analyzed by using 100 bootstrapped data sets (6).

Other methods. Growth yields were determined by weight; cultures of 0.5 liters were centrifuged, washed twice with $50 \mathrm{mM} \mathrm{NaCl}$, and dried overnight at $100^{\circ} \mathrm{C}$. Biomass dry-weight data were converted to molar units with the assumption that the formula of the organic fraction of the biomass of bacterial cells was $\mathrm{C}_{5} \mathrm{H}_{7} \mathrm{O}_{2} \mathrm{~N}$ (molar units $=113$ ) (19). The $\mathrm{G}+\mathrm{C}$ content of the cellular DNA was determined by HPLC (21) at the Deutsche Sammlung von Mikroorganismen. Gram staining was done according to standard procedures (22).

Nucleotide sequence accession number. The $16 \mathrm{~S}$ rDNA sequence of strain $\mathrm{U}^{\mathrm{T}}$ has been deposited in the EMBL nucleotide sequence database under accession no. X90488. The EMBL accession numbers for the reference sequences are as follows: Eubacterium moniliforme, L34622; Clostridium baratii, X68175; Clostridium paraputrificum, X73445; Clostridium beijerinckii, X68180; Clostridium collagenovorans, X73439; Clostridium tyrobutyricum, M59113; Clostridium putrificum, X73442; Clostridium pfennigii, X77838; Caloramator fervidus, L09187; Caloramator indicus, X75788; Clostridium thermolacticum, X72870; Clostridium aldrichii, X71846; Clostridium termitidis, X71854; Clostridium cellobioparum, X71856; "Thermoanaerobacter cellulolyticus," L09183; "Anaerocellum thermophilum," L09180; Heliobacterium modesticaldum, U14559; Thermoanaerobacter brockii subsp. lactiethylicus, U14330; Moorella thermoacetica, M59121; Selenomonas nminantium, M62702; Clostridium herbivorans, L34418; and Escherichia coli, J01859.

\section{RESULTS}

Enrichment and isolation of strain $\mathbf{U}^{T}$. Strain $\mathrm{U}^{\mathrm{T}}$ was isolated from mesophilic granular sludge from a lab-scale UASB reactor that was treating whey. After incubation at $55^{\circ} \mathrm{C}$ for $24 \mathrm{~h}$, growth was observed in the enrichment. Microscopic examination revealed an abundance of rod-shaped bacteria.
This enrichment was serially diluted and transferred to anaerobic roll tubes containing the same medium, and the tubes were incubated at $55^{\circ} \mathrm{C}$ until colonies developed. Colonies (4 $\mathrm{mm}$ in diameter) developed on and in the agar after incubation at $55^{\circ} \mathrm{C}$ for $24 \mathrm{~h}$. Surface colonies were golden, circular, smooth, opaque, and bluish around the entire edge. Colonies inside the agar were lens shaped. Five colonies were chosen and transferred to liquid medium, diluted, inoculated into new roll tubes, and incubated at $55^{\circ} \mathrm{C}$. This process was repeated twice. The surface and embedded colonies gave rise to the same colonial morphology. One of the isolates obtained from a surface colony was designated strain $\mathrm{U}^{\mathrm{T}}$.

Morphology and cytology. Cells of strain $\mathrm{U}^{\mathrm{T}}$ were straight or slightly curved rods with pointed ends occurring as single cells or in pairs. They were 2.4 to $4 \mu \mathrm{m}$ long and $0.4 \mu \mathrm{m}$ wide. The cells were peritrichous (Fig. 1a) and exhibited tumbling motility, but this property was quickly lost when they were exposed to air. Cells in liquid cultures sedimented during aging. When grown at an initial $\mathrm{pH}$ of 8.5 , the cells became thinner and formed very long filament-like threads. Lysis of the cells occurred at the beginning of the stationary phase when the organism was grown on sugars. Spores were never observed in basal medium containing glucose, but spores were present after $48 \mathrm{~h}$ of incubation at $55^{\circ} \mathrm{C}$ in cultures grown with limiting amounts of yeast extract or protein as the sole carbon and energy source. Cultures with spores could be pasteurized at $90^{\circ} \mathrm{C}$ for $2 \mathrm{~h}$; growth occurred when these cultures were inoculated into fresh medium. The cellular morphology and fermentation products of pasteurized cultures were identical to 
TABLE 1. End products of protein and Casamino Acid fermentations by strain $\mathrm{U}^{\mathrm{T}}$

\begin{tabular}{lrccccc}
\hline \multirow{2}{*}{$\begin{array}{c}\text { Substrate } \\
\text { (concn [g/liter]) }\end{array}$} & \multicolumn{5}{c}{ Product formed (mmol/liter) } \\
\cline { 2 - 7 } & Acetate & Formate & Bc-VFA $^{a}$ & Propionate & Butyrate & $\mathrm{H}_{2}$ \\
\hline Casein (5) & 8.4 & 2.6 & 4.1 & 2.0 & 1.1 & 7.1 \\
Gelatin (5) & 15.4 & 0.5 & 2.7 & 1.1 & 0.8 & 1.2 \\
Peptone (5) & 10.6 & 2.5 & 4.5 & 4.6 & 1.5 & 8.5 \\
Casamino Acids (3) & 5.6 & 1.4 & 2.3 & 1.2 & 0.5 & 2.8 \\
\hline
\end{tabular}

${ }^{a} \mathrm{Bc}-\mathrm{VFA}$, branched-chain volatile fatty acids: isovalerate, isobutyrate, and 2-methylbutyrate.

those of unpasteurized cultures when both were grown on glucose, glutamate, and gelatin. Furthermore, the purity of these cultures was also confirmed by the observation of only one colony type after $48 \mathrm{~h}$ of anaerobic incubation at $55^{\circ} \mathrm{C}$ on gelatin agar plates. Exponentially growing cells stained gram negative but had a negative $\mathrm{KOH}$ test reaction (7). Electron micrographs of thin sections of cells of strain $U^{T}$ revealed a two-layer structure (Fig. 1b). The outside layer stained intensely, whereas the inner layer adjacent to the cytoplasmic membrane was less dense.

Physiological characterization. (i) Growth requirements. Strain $\mathrm{U}^{\mathrm{T}}$ required strictly anaerobic conditions for growth. Growth was observed only in the reduced, lower portions of the shake tubes. The addition of $0.02 \%$ yeast extract was necessary for growth in otherwise defined media.

(ii) Optimal growth conditions. The temperature range for growth of strain $\mathrm{U}^{\mathrm{T}}$ at an initial $\mathrm{pH}$ of 7.0 was from 30 to $68^{\circ} \mathrm{C}$, with an optimum temperature of $55^{\circ} \mathrm{C}$. Growth was observed at initial $\mathrm{pH}$ values between 6.0 and 9.5 (final $\mathrm{pH}$ values being 5.5 and 8.7 , respectively), with a maximum growth rate between $\mathrm{pH} 7.0$ and 7.5. The doubling time of the bacterium on glucose at $\mathrm{pH} 7.0$ and $55^{\circ} \mathrm{C}$ was $30 \mathrm{~min}$.

(iii) Substrate utilization and fermentation products. The isolate fermented proteins and complex protein-derived substrates such as peptone and Casamino Acids. Acetate was a major end product (Table 1). Thermoactive, extracellular protease production was observed when cells were grown on media with protein (data not shown). Glutamate, threonine, methionine, aspartate, arginine, histidine, leucine, and valine were utilized as carbon and energy sources. The fermentation products from glutamate $(10 \mathrm{mM})$ included acetate $(15.9 \mathrm{mM})$, formate $(2.7 \mathrm{mM})$, alanine $(1.9 \mathrm{mM})$, bicarbonate $(5.2 \mathrm{mM})$ (which was not measured but was calculated by subtracting the amount of formate from half of the amount of acetate), and hydrogen ( $2.2 \mathrm{mmol}$ per liter). The carbon recovery and available-hydrogen-balance values were 93 and $81 \%$, respectively. Methionine and threonine were converted to propionate, hydrogen, and formate. Leucine and valine were degraded to isovalerate and isobutyrate, respectively, and hydrogen. When the yeast extract concentration in the medium was increased to $1 \mathrm{~g} /$ liter, strain $\mathrm{U}^{\mathrm{T}}$ performed a nearly complete, coupled oxidation and reduction of $4 \mathrm{mM}$ leucine and $8 \mathrm{mM}$ glycine to 3.7 $\mathrm{mM}$ isovalerate and $9.8 \mathrm{mM}$ acetate, respectively, with no concomitant production of hydrogen or formate. This stoichiometry is in accordance with that of a Stickland reaction.

Strain $\mathrm{U}^{\mathrm{T}}$ also grew on saccharides and starch. Glucose, fructose, mannose, cellobiose, and starch were utilized. Glucose $(10 \mathrm{mM})$ was converted to acetate $(8.9 \mathrm{mM})$, ethanol $(8.5$ $\mathrm{mM})$, formate $(5.8 \mathrm{mM})$, lactate $(0.5 \mathrm{mM})$, and hydrogen $(11.0$ mmol per liter). No alanine formation was detected.

The molar growth yields on glutamate and glucose with $0.02 \%$ yeast extract, corrected for growth on yeast extract only, were 2.0 and $9.2 \mathrm{~g}$ (dry weight) of cells $\cdot \mathrm{mol}$ of substrate ${ }^{-1}$, respectively.

Ornithine, proline, acetate, $\mathrm{H}_{2}-\mathrm{CO}_{2},(80: 20)$, formate, $\alpha$-ketoglutarate, lactose, xylose, malate, xylan, and cellulose were not utilized by strain $\mathrm{U}^{\mathrm{T}}$.

The mass balance of glutamate fermentation in the presence of electron acceptors such as sulfate, sulfite, thiosulfate, nitrate, or fumarate was not affected, indicating the absence of anaerobic respiration. Fumarate reduction was not observed in the presence of pyruvate, hydrogen, or formate as a possible electron donor.

DNA base composition. The $\mathrm{G}+\mathrm{C}$ content of the DNA of strain $\mathrm{U}^{\mathrm{T}}$ was $31 \%$, as determined by HPLC.

Phylogenetic analysis. More than $92 \%$ of the 16S rRNA gene was sequenced from position 32 to position 1468 ( $E$. coli numbering of Brosius et al. [2]). FASTA comparisons revealed that the closest relatives of strain $\mathrm{U}^{\mathrm{T}}$ were $C$. indicus and $C$. fervidus, with 96.6 and $91.1 \%$ sequence similarity, respectively, followed by members of Clostridium cluster I as defined by Collins et al. (4). Sequence alignment was performed from positions 32 to 1419 , and a phylogenetic tree was constructed with representatives of the various phyla of the domain $\mathrm{Bac}$ teria. The resulting dendrogram, depicted in Fig. 2, shows the positioning of strain $\mathrm{U}^{\mathrm{T}}$ within a clearly defined cluster formed by members of the genus Caloramator.

\section{DISCUSSION}

Although many mesophilic anaerobic proteolytic bacteria present in anaerobic reactors have been described $(9,31)$, most of the moderately thermophilic anaerobes which have been isolated are saccharolytic (38). Proteolytic activity has been demonstrated in some glycolytic thermophilic anaerobic bacteria, but these strains cannot grow on protein as the sole carbon and energy source and thus are not considered proteolytic bacteria (38). To our knowledge, only four moderately thermophilic proteolytic bacteria have been described $(5,13$, $24,35)$. The new isolate, strain $\mathrm{U}^{\mathbf{T}}$, differs in several important morphological, physiological, and phylogenetic characteristics from these bacteria. $C$. proteolyticus and $T$. leptospartum are non-spore-forming, nonmotile rods, have optimum growth temperatures above $60^{\circ} \mathrm{C}$, have higher DNA G+C contents (43 mol\%) than strain $\mathrm{U}^{\mathrm{T}}$, and ferment xylose and lactose but not Casamino Acids. Strain $\mathrm{U}^{\mathrm{T}}$ also has a noticeably more rapid growth rate (doubling times of $30 \mathrm{~min}$ ) than do $C$. proteolyticus and T. leptospartum (doubling times of $8.6 \mathrm{~h}$ ). Phylogenetically, C. proteolyticus is related to members of the order Thermotogales (28). The phylogenetic position of $T$. leptospartum is at present unknown. Örlygsson has described a moderately thermophilic bacterium, Clostridium strain P2, which markedly differs phenotypically from strain $\mathrm{U}^{\mathrm{T}}$. Clostridium strain $\mathrm{P} 2$ has a higher optimum $\mathrm{pH}(9.0)$ than does strain $\mathrm{U}^{\mathrm{T}}$, it does not utilize glutamate, aspartate, histidine, gelatin, or cellobiose, and the degradation of branched-chain amino acids in the presence of glycine could not be demonstrated. Furthermore, alanine is a major end product of Clostridium strain P2 from sugar fermentation, and minor amounts of butyrate, but no ethanol, are produced. Very recently a new anaerobic proteolytic alkaliphilic thermophile has been described. Anaerobranca horikoshii, however, is phylogenetically distant from strain $\mathrm{U}^{\mathbf{T}}$ and does not ferment sugars, starch, or Casamino Acids (5).

Phylogenetic analysis revealed that strain $\mathrm{U}^{\mathrm{T}}$ is peripherally related to the sporulating gram-positive clostridia, more specifically to cluster I (4), as shown in Fig. 2. Its closest relatives are two members of a distinct line of descent, species belonging to the recently named genus Caloramator $(3,26)$. The boot- 


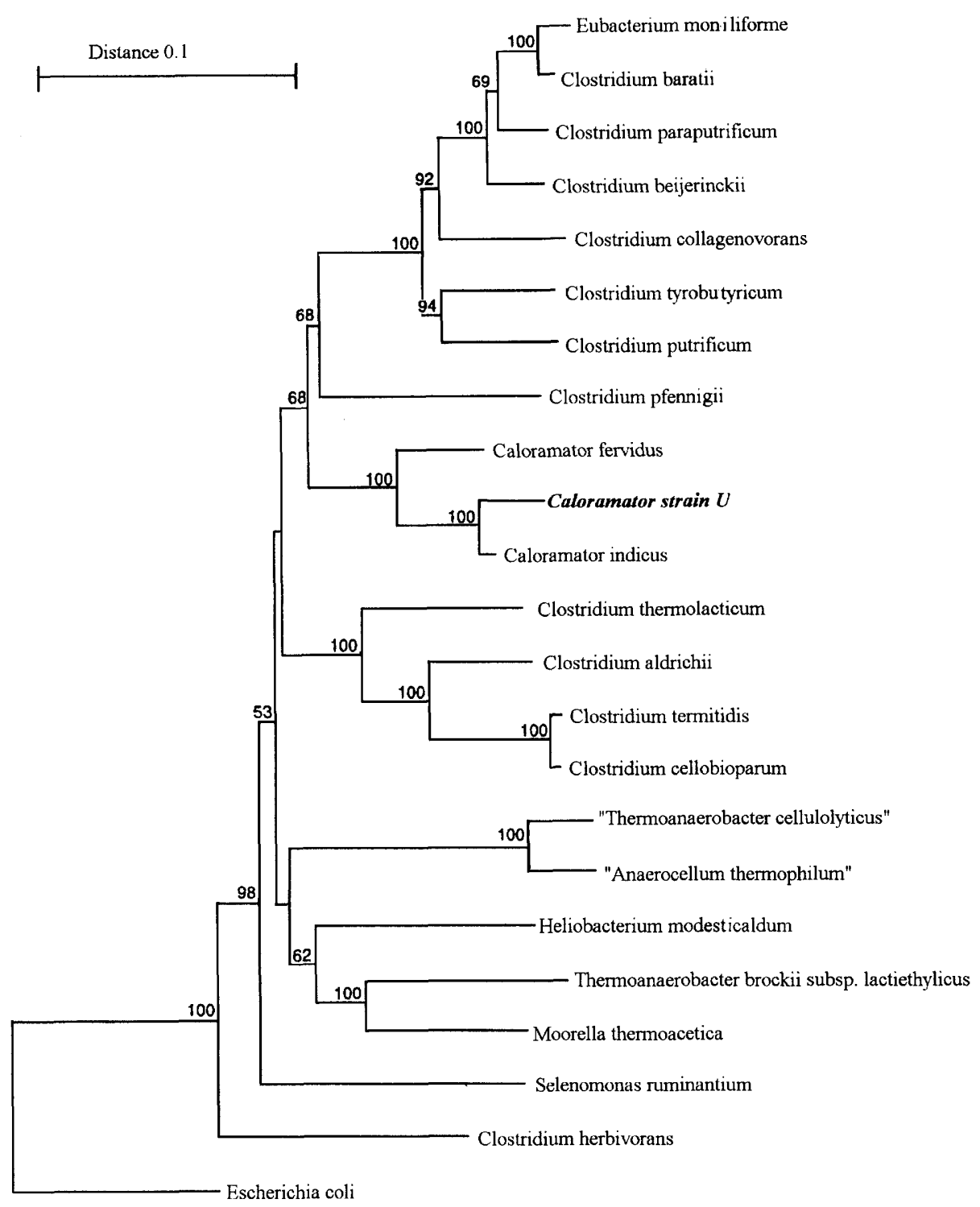

FIG. 2. Phylogenetic tree showing the relationship of novel strain $\mathrm{U}^{\mathrm{T}}$ to selected bacteria based on a comparison of $16 \mathrm{~S}$ rRNA sequences. E. coli was used as the outgroup. The bar corresponds to a $10 \%$ difference in nucleotide sequences, as determined by measuring the lengths of the horizontal lines connecting any two organisms. The numbers shown next to the nodes indicate percent bootstrap values from 100 data sets. Only bootstrap values greater than $50 \%$ are shown.

strap analysis of the data denotes a significant association between strain $\mathrm{U}^{\mathrm{T}}$ and both Caloramator species. The closest relation is to $C$. indicus, although it differs by $3.4 \%$ in the $16 \mathrm{~S}$ rRNA sequence. According to Stackebrandt and Goebel (33), strains belonging to the same genus that exhibit less than $97 \%$ $16 \mathrm{~S}$ rRNA sequence similarity should be considered members of different species.

Previously described guidelines suggest that the maximum range of $\mathrm{G}+\mathrm{C}$ contents that is allowed for a species is $5 \mathrm{~mol} \%$ (18). The $\mathrm{G}+\mathrm{C}$ contents of previously described thermophilic bacteria range from 30 to $55 \mathrm{~mol} \%$, with the exception of $C$. indicus, for which a value of $25.6 \mathrm{~mol} \%$ was reported (3). The $\mathrm{G}+\mathrm{C}$ content of strain $\mathrm{U}^{\mathrm{T}}$ is $31 \mathrm{~mol} \%$. The difference in $\mathrm{G}+\mathrm{C}$ content between strain $\mathrm{U}^{\mathrm{T}}$ and previously described species of the genus Caloramator warrants its classification as a member of a separate species (Table 2).

Morphological and physiological characteristics of strain $\mathrm{U}^{\mathrm{T}}$ are directly compared with the characteristics of the other strains belonging to the genus Caloramator in Table 2. Strain $\mathrm{U}^{\mathrm{T}}$ stains gram negative, but the cell wall ultrastructure does not reveal an outer membrane (Fig. 1b). This cell wall can be clearly differentiated from the single-layered ultrastructures observed in both $C$. fervidus and $C$. indicus. Strain $\mathrm{U}^{\mathrm{T}}$ forms thermoresistant spores, supporting the theory that the presence of spore-forming and non-spore-forming species in the same genus is not uncommon among anaerobic thermophilic bacteria $(4,28)$.

Similar end products are obtained from the fermentation of glucose by the three Caloramator species, with the exception of formate production by strain $\mathrm{U}^{\mathrm{T}}$. Other distinguishing characteristics of strain $\mathrm{U}^{\mathrm{T}}$ include its substrate utilization, low optimum growth temperature, and growth temperature range (Table 2). The habitats from which these organisms were isolated are also different. Both $C$. fervidus and $C$. indicus were isolated from geothermally heated waters, while strain $\mathrm{U}^{\mathrm{T}}$ originated from a mesophilic reactor. 
TABLE 2. Selected properties of strain $\mathrm{U}^{\mathrm{T}}$, C. indicus, and C. fervidus ${ }^{a}$

\begin{tabular}{|c|c|c|c|c|c|c|c|c|c|c|c|}
\hline \multirow[b]{2}{*}{ Organism } & \multirow{2}{*}{$\begin{array}{c}\text { Spore } \\
\text { formation }\end{array}$} & \multirow[b]{2}{*}{ Motility } & \multicolumn{2}{|c|}{ Growth temp $\left({ }^{\circ} \mathrm{C}\right)$} & \multirow{2}{*}{$\begin{array}{l}\text { Optimum } \\
\text { pH }\end{array}$} & \multirow{2}{*}{$\begin{array}{l}\text { Fermentation end } \\
\text { products from } \\
{\text { glucose } \mathrm{e}^{b}}^{b}\end{array}$} & \multicolumn{4}{|c|}{ Utilization of: } & \multirow{2}{*}{$\begin{array}{l}\mathrm{G}+\mathrm{C} \\
\text { content } \\
(\mathrm{mol} \%)\end{array}$} \\
\hline & & & Range & Optimum & & & Lactose & Xylan & Glutamate & $\begin{array}{l}\text { Casamino } \\
\text { Acids }\end{array}$ & \\
\hline Strain $U^{T}$ & + & + & $\geq 30-<68$ & 55 & $7.0-7.5$ & $\mathrm{~A}, \mathrm{E}, \mathrm{F}, 1, \mathrm{H}_{2}$ & - & - & + & + & 31 \\
\hline C. indicus & - & - & $>37-<75$ & $60-65$ & 8.1 & $\mathrm{E}, \mathrm{A}, \mathrm{L}, \mathrm{H}_{2}$ & + & $\mathrm{NR}^{c}$ & NR & NR & 25.6 \\
\hline C. fervidus & + & + & $>37-<80$ & 68 & $7.0-7.5$ & $\mathrm{~A}, 1, \mathrm{e}, \mathrm{H}_{2}$ & NR & + & - & - & 39 \\
\hline
\end{tabular}

${ }^{a}$ Data from this study and references 3 and 26.

${ }^{a} \mathrm{~A}$, acetate; $\mathrm{E}$ and e, ethanol; F, formate; $\mathrm{L}$ and 1 , lactate; $\mathrm{H}_{2}$, hydrogen. Uppercase letters indicate major products, and lowercase letters indicate minor products. ${ }^{c} \mathrm{NR}$, not reported.

Strain $\mathrm{U}^{\mathrm{T}}$ is physiologically and phylogenetically different from all moderately thermophilic proteolytic or saccharolytic anaerobes described previously. Nevertheless, the phylogenetic evidence indicates it is closely related to $C$. indicus and $C$. fervidus. Thus, we propose to assign the described strain $\mathrm{U}^{\mathrm{T}}$ to the genus Caloramator as a new species, C. proteoclasticus.

Description of Caloramator proteoclasticus. Caloramator proteoclasticus (pro.te.o.clas'ti.cus. Gr. adj. protos, first; Gr. adj. clasticus, breaking, from Gr. part. perf. klastos, broken; M.L. masc. adj. proteoclasticus, protein breaking). Cells are strictly anaerobic, straight or slightly curved rods, 2.4 to $4 \mu \mathrm{m}$ long and $0.4 \mu \mathrm{m}$ wide, with pointed ends. Stains gram negative but cell wall type is atypical gram positive. Peritrichous motility and thermoresistant spores are observed in late exponential phase in cultures grown on yeast extract and gelatin. Lysis occurs in stationary phase in cultures grown on sugars.

Chemoorganotrophic and moderately thermophilic. The minimum temperature for growth is $30^{\circ} \mathrm{C}$, optimum temperature is $55^{\circ} \mathrm{C}$, and the maximum temperature is $68^{\circ} \mathrm{C}$; $\mathrm{pH}$ range for growth is 6.0 to 9.5 , and optimum $\mathrm{pH}$ is 7.0 to 7.5 .

Casein, gelatin, peptone, and Casamino Acids are fermented to acetate, propionate, butyrate, branched-chain fatty acids, formate, and hydrogen. Glutamate, arginine, and histidine are fermented to acetate, hydrogen, and formate. Alanine is produced as a reduced end product from glutamate. Threonine and methionine are fermented to propionate, hydrogen, and formate. Branched-chain amino acids, alanine and glycine, are degraded, with a yeast extract concentration of $1 \mathrm{~g} /$ liter in the medium, to branched-chain fatty acids and acetate, respectively. A complete Stickland reaction is observed with leucine and glycine. Growth is observed with glucose, fructose, mannose, and cellobiose. Starch and pyruvate are also utilized. Major end products are acetate, lactate, ethanol, formate, and hydrogen. Ornithine, proline, acetate, $\mathrm{H}_{2}-\mathrm{CO}_{2}(80: 20)$, formate, $\alpha$-ketoglutarate, lactose, xylose, malate, xylan, and cellulose are not fermented. Sulfate, thiosulfate, nitrate, and fumarate are not reduced.

The cellular DNA G $+\mathrm{C}$ content is $31 \mathrm{~mol} \%$, as determined by HPLC.

The type strain is strain U (= DSM 10124).

Isolated from a mesophilic UASB reactor that was fermenting whey.

\section{ACKNOWLEDGMENTS}

We are deeply grateful to Francis Cottaar for performing the electron microscopy and Wim Roelofsen for carrying out the amino acid analysis. We are also indebted to Renée de Vrijer for her patient work in the PCR amplification, cloning, and sequencing. We also thank Diederik Wolters and Hugo Ramírez for vital help with the final phylogenetic analysis. S.T. appreciates very much the great hospitality of everyone at the Department of Microbiology of Wageningen Agricultural University.

Financial grants from the Organization of American States and
Wageningen Agricultural University of The Netherlands are gratefully acknowledged.

\section{REFERENCES}

1. Breznak, J. A., and R. N. Costilow. 1994. Physicochemical factors in growth, p. 137-154. In P. Gerhardt, R. G. E. Murray, W. A. Wood, and N. R. Krieg (ed.), Methods for general and molecular bacteriology. American Society for Microbiology, Washington, D.C.

2. Brosius, J., J. L. Palmer, J. P. Kennedy, and H. F. Noller. 1987. Complete nucleotide sequence of a $16 \mathrm{~S}$ ribosomal RNA gene from Escherichia coli. Proc. Natl. Acad. Sci. USA 75:4801-4805.

3. Chrisostomos, S., B. K. C. Patel, P. P. Dwivedi, and S. E. Denman. 1996. Caloramator indicus sp. nov., a new thermophilic anaerobic bacterium isolated from the deep-seated nonvolcanically heated waters of an Indian artesian aquifer. Int. J. Syst. Bacteriol. 46:497-501.

4. Collins, M. D., P. A. Lawson, A. Willems, J. J. Cordoba, J. FernandezGarayzabal, P. Garcia, J. Cai, H. Hippe, and J. A. E. Farrow. 1994. The phylogeny of the genus Clostridium: proposal of five new genera and eleven new species combinations. Int. J. Syst. Bacteriol. 44:812-826.

5. Engle, M., Y. Li, C. Woese, and J. Wiegel. 1995. Isolation and characterization of a novel alkalitolerant thermophile, Anaerobranca horikoshii gen. nov., sp. nov. Int. J. Syst. Bacteriol. 45:454-461.

6. Felsenstein, J. 1985. Confidence limits on phylogenies: an approach using the bootstrap. Evolution 39:783-791.

7. Gregersen, L. 1978. Rapid method for distinction of gram negative from gram positive bacteria. J. Appl. Biochem. 5:123-126.

8. Harmsen, H. J. M., H. M. P. Kengen, A. D. L. Akkermans, and A. J. M. Stams. 1995. Phylogenetic analysis of two syntrophic propionate-oxidizing bacteria in enrichment cultures. Syst. Appl. Microbiol. 18:67-73.

9. Hobson, P. N., and R. J. Wallace. 1982. Microbial ecology and activities in the rumen. Crit. Rev. Microbiol. 9:253-320.

10. Holdeman, L. V., E. P. Cato, and W. E. C. Moore. 1977. Culture methods: use of pre-reduced media, p. 117-149. In L. V. Holdeman, E. P. Cato, and W. E. C. Moore (ed.), Anaerobic laboratory manual, 4th ed. Anaerobe Laboratory, Virginia Polytechnic Institute and State University, Blacksburg.

11. Houwen, F. P., C. Dijkkema, C. H. H. Schoenmakers, A. J. M. Stams, and A. J. B. Zehnder. $1987 .{ }^{13} \mathrm{C}-\mathrm{NMR}$ study of propionate degradation by a methanogenic coculture. FEMS Microbiol. Lett. 41:269-274.

12. Hungate, R. E. 1969. A roll tube method for cultivation of strict anaerobes. Methods Microbiol. 3b:117-132.

13. Kersters, I., G. M. Maestrojuan, U. Torck, M. Vancanney, K. Kersters, and W. Verstraete. 1994. Isolation of Coprothermobacter proteolyticus from an anaerobic digest and further characterization of the species. Syst. Appl. Microbiol. 17:289-295.

14. Kimura, M. 1980. A simple method for estimating evolutionary rate of base substitutions through comparative studies of nucleotide sequences. J. Mol. Evol. 16:111-120.

15. Koster, I. W., and G. Lettinga. 1988. Anaerobic digestion at extreme ammonia concentrations. Biol. Wastes 25:51-59.

16. Lane, D. J. 1991. 16S/23S rRNA sequencing, p. 115-175. In E. Stackebrandt and M. Goodfellow (ed.), Nucleic acid techniques in bacterial systematics. J. Wiley \& Sons, Chichester, England.

17. Lettinga, G. 1995. Anaerobic digestion and wastewater treatment systems. Antonie Leeuwenhoek 67:3-28.

18. Logan, N. A. 1994. Bacterial systematics. Blackwell Scientific Publications, Oxford, England.

19. McCarty, P. L. 1975. Stoichiometry of biological reactions. Prog. Water Technol. 7:157-170.

20. McInerney, M. J. 1988. Anaerobic hydrolysis and fermentation of fats and proteins, p. 373-415. In A. J. B. Zehnder (ed.), Biology of anaerobic microorganisms. John Wiley \& Sons, New York, N.Y.

21. Mesbah, M., U. Premachandran, and W. B. Whitman. 1989. Precise measurement of the $\mathrm{G}+\mathrm{C}$ content of deoxyribonucleic acid by high-performance liquid chromatography. Int. J. Syst. Bacteriol. 39:159-167.

22. Murray, R. G. E., R. N. Doetsch, and C. F. Robinow. 1994. Determinative 
and cytological light microscopy, p. 21-41. In P. Gerhardt, R. G. E. Murray W. A. Wood, and N. R. Krieg (ed.), Methods for general and molecular bacteriology. American Society for Microbiology, Washington, D.C.

23. Muxí, L., L. Zunino, S. Tarlera, and M. Soubes. 1992. Characterization of a methanogenic sludge to be used as inoculum for a high-rate reactor. World J. Microbiol. Biotechnol. 8:632-634.

24. Orlygsson, J. 1994. The role of interspecies hydrogen transfer on thermophilic protein and amino acid metabolism. Ph.D. thesis. Swedish University of Agricultural Sciences, Uppsala, Sweden.

25. Oude Elferink, S. J. W. H., R. N. Maas, H. M. Harmsen, and A. J. M. Stams. 1995. Desulforhabdus amnigenus gen. nov. sp. nov., a sulfate reducer isolated from anaerobic granular sludge. Arch. Microbiol. 164:119-124.

26. Patel, B. K. C., C. Monk, H. Littleworth, H. W. Morgan, and R. M. Daniel 1987. Clostridium fervidus sp. nov., a new chemoorganotrophic acetogenic thermophile. Int. J. Syst. Bacteriol, 37:123-126.

27. Pearson, W. R., and D. J. Lipman. 1988. Improved tools for biological sequence comparison. Proc. Natl. Acad. Sci. USA 85:2444-2448.

28. Rainey, F. A., N. L. Ward, H. W. Morgan, R. Toalster, and E. Stackebrandt 1993. Phylogenetic analysis of anaerobic thermophilic bacteria: aid for their reclassification. J. Bacteriol. 175:4772-4779.

29. Saitou, N., and M. Nei. 1987. The neighbor-joining method: a new method for reconstructing phylogenetic trees. Mol. Biol. Evol. 4:406-425.

30. Schink, B. 1988. Principles and limits of anaerobic degradation: environmen- tal and technological aspects, p. 771-828. In A. J. B. Zehnder (ed.), Biology of anaerobic microorganisms. John Wiley \& Sons, New York, N.Y.

31. Siebert, M. L., and D. F. Toerien. 1969. The proteolytic bacteria present in the anaerobic digestion of raw sewage sludge. Water Res. 3:241-250.

32. Speece, R. E. 1995. Anaerobic biotechnology for industrial wastewaters, p. 3-6. Vanderbilt University Press, Nashville, Tenn.

33. Stackebrandt, E., and B. M. Goebel. 1994. Taxonomic note: a place for DNA-DNA reassociation and 16S rRNA sequence analysis in the present species definition in bacteriology. Int. J. Syst. Bacteriol. 44:846-849.

34. Stams, A. J. M., J. B. Van Dijk, C. Dijkema, and C. M. Plugge. 1993. Growth of syntrophic propionate-oxidizing bacteria with fumarate in the absence of methanogenic bacteria. Appl. Environ. Microbiol. 59:1114-1119.

35. Toda, Y., T. Saiki, T. Uozomi, and T. Beppu. 1988. Isolation and characterization of a protease-producing thermophilic anaerobic bacterium, Thermobacteroides leptospartum sp. nov. Agric. Biol. Chem. 52:1339-1344.

36. Van De Peer, Y., and R. De Wachter. 1993. TREECON: a software package for the construction and drawing of evolutionary trees. Comput. Appl. Biosci. 9:177-182

37. Van Lier, J. B. 1995. Thermophilic anaerobic wastewater treatment: temperature aspects and process stability. Ph.D. thesis. Wageningen Agricultural University, Wageningen, The Netherlands.

38. Wiegel, J. 1992. The obligate thermophilic bacteria, p. 105-184. In J. K Kristjansson (ed.), Thermophilic bacteria. CRC Press, Boca Raton, Fla. 